|Derleme Makalesi / Review Article |

\title{
Türkiye'de COVID-19 Salgını Sürecinde Milli Eğitim Bakanlığı Tarafından Atılan Politika Adımları
}

\section{Educational Policy Actions by the Ministry of National Education in the times of COVID-19}

\section{Mahmut ÖZER ${ }^{1}$}

\section{Anahtar Kelimeler \\ COVID-19 \\ Koronavirüs \\ Milli Eğitim Bakanlığı \\ Politika Adımları}

Keywords
COVID-19
Coronavirus
Ministry of National
Education
Policy Actions

Başvuru Tarihi/Received 17.04.2020

Kabul Tarihi /Accepted 28.04.2020
Öz

Ülkeler tüm dünyada devam eden COVID-19 salgını nedeniyle oluşan yeni durumlarla mücadele etmekte, eğitim yöneticileri öğrencilerin eğitim ihtiyaçlarını çevrimiçi platformlar ve uzaktan eğitim çözümleri aracılığıyla karşılamak için çaba göstermektedir. Milyarlarca öğrenci ve milyonlarca eğitimci salgın nedeniyle okulların kapanması ve diğer sınırlamalardan etkilenmiştir. Bu çalışmada, Türkiye'de COVID-19 salgını sürecinde eğitim hizmetlerinin devam etmesi ve toplumun intiyaçlarının eğitim kurumlarında gerçekleştirilen üretimlerle karşılanması için Milli Eğitim Bakanlığı (MEB) tarafından atılan adımlar değerlendirilmiştir. Türkiye'de okulların kapanması kararı ile MEB etkin bir uzaktan eğitim sistemi kurmak için dijital eğitim platformu olarak hizmet veren Eğitim Bilişim Ağı'nın (EBA) altyapısını güçlendirmiş ve Türkiye Radyo Televizyon Kurumu (TRT) ile işbirliği yapmıştır. Mesleki ve teknik eğitim (MTEK) kurumları üretim ve uyum potansiyellerinden yararlanarak toplumun salgın günlerindeki taleplerini karşılamada çok büyük bir katkı sağlamıştır. COVID-19'un yol açtığı olumsuz psikolojik etkiler ile başa çıkmak için MEB, yardım hattı ve rehberlerden oluşan bir psikososyal destek sistemi kurmuştur. Sonuç olarak $M E B$, öğrencileri akademik ve sosyal açıdan destekleyen bir uzaktan eğitim sistemi kurmuş, psikososyal destek sistemini hayata geçirmiş ve MTEK kurumlarının salgın günlerinde ihtiyaç duyulan materyalleri üretmesini sağlamışıı.

\section{Abstract}

Countries struggle with the new situations due to COVID-19 pandemic around the world, and educational authorities strive for meeting the educational needs of students by using different online portals and distance education solutions. Billions of students and millions of educators are affected by school closures and other restrictions. In this study, I review the educational policy actions in Turkey by Ministry of National Education (MoNE) to maintain educational services, and to meet the needs of society with the productions of educational institutions in COVID-19 pandemic days. With school closures in Turkey, MoNE strengthened the infrastructure of digital educational portal, Educational Informatics Network (EBA) and collaborated with Turkish Radio and Television Corporation (TRT) to establish an effective distance education system. Vocational education and training (VET) institutions have made great contributions to meet the needs of the society via its potential in production and adaptation. To cope with the negative psychological effects of COVID-19, MoNE established a psychosocial support system involving specific helpline and guides. Consequently, MoNE quickly established an extensive distance education environment which supports students academically and socially, developed psychosocial support system, and used VET institutions to produce the needed materials and equipment in pandemic days.

${ }^{1}$ Milli Eğitim Bakanlığı, Ankara, TÜRKiYE; https://orcid.org/0000-0001-8722-8670 


\section{INTRODUCTION}

Since the end of 2019, a coronavirus type has started to threaten the human life in Wuhan (China). Due to the scale of the threat, it is labeled as a "pandemic" by World Health Organization (WHO) in $11^{\text {th }}$ of March. It is the first pandemic announcement by WHO which is caused by a type of coronavirus and WHO warns all local authorities to raise their health emergencies to maximum level (WHO, 2020).

An estimation by UNESCO shows that more than 1,5 billion of students and 63 million of educators are affected by school closures in 188 countries as the date of March 27, 2020 (UNESCO, 2020). Due to uncertainty on schedules, applications for most graduate programs are delayed to a particular time or canceled around the world (OECD, 2020).

At the early stages of pandemic, it is perceived as a matter of public health, however, characteristics of fast contamination and stamina in diverse objects make COVID-19 a more critical issue (Burgess \& Sievertsen, 2020). Political authorities begin to take precautions to slow down the velocity of COVID-19 infection (OECD, 2020). Travel bans and social distancing measures were the first steps taken by almost all countries, and these steps are followed with a curfew in some countries.

In these circumstances, education was affected greatly as one main daily activity of millions of students, teachers and parents around of the world (ETF, 2020; Hopegood; 2020; OECD, 2020; Saavedra, 2020; UNESCO, 2020). In most countries, schools are closed and education is provided through distance education platforms (ETF, 2020; Reimers, 2020). It is a dilemma for all educational authorities. Because while distance education and other digital solutions are the best way to cope with COVID-19, these methods also bring the risk of increasing educational inequity (Moreno \& Gortazar, 2020). Due to the fact that students do not have same level of digital competencies, computers and internet connections, policymakers need to consider these differences between student groups.

In this study, I review the urgent policy responses by MoNE in Turkey to COVID-19 in different areas, including the alternative online educational portal and other distance education services, production of urgent materials and equipment to prevent the spread of the pandemic, and lastly a new helpline for psychosocial support.

\section{Covid-19 Pandemic in Turkey}

Turkey kept the threat of COVID-19 out of its borders until $11^{\text {th }}$ of March. Since then, the number of cases has been increasing. As of $15^{\text {th }}$ of April, about one month after announcing the first official COVID-19 case, there are 69,392 known cases, 1,518 deaths and 5,674 recovered patients in Turkey (Ministry of Health-COVID 19 Database). The changes in the number of COVID-19 positive cases with comparison of some other countries is given in Figure 1. As it is seen in Figure 1, numbers of the cases with COVID-19 positive have yet to reach the expected peak level in Turkey and have continued to increase with lower ratio. Ministry of Health and its Scientific Council evaluate the situation constantly, and precautionary measures have become stricter with their feedbacks.

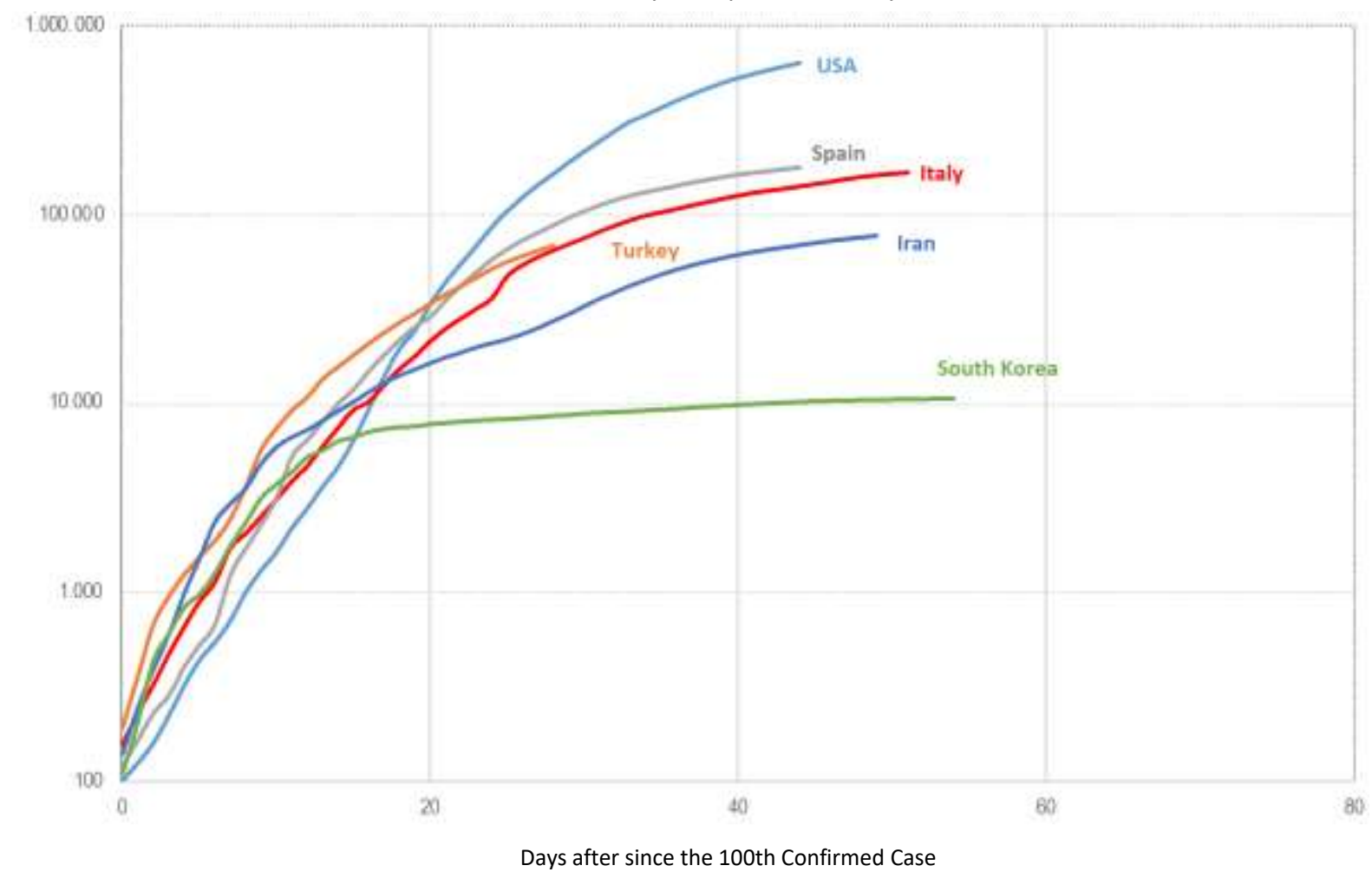

Figure 1. The COVID-19 positive cases in Iran, Italy, South Korea, Spain, Turkey and United States*

* World Health Organization Data, 15.4.2020 
Since the first stages of COVID-19 pandemic, Ministry of National Education (MoNE) has maintained the communications with Ministry of Health and its Scientific Council. Considering an education system with approximately 18 millions of students and 1 million teachers, MoNE prioritized the health and well-being of all educational stakeholders, and decided to maintain school closures until the end of April 2020 based on the recommendations of the Scientific Council.

\section{Distance Education}

With the school closures, continuing of education via alternative platforms become crucial in Turkey. Distance education is the key element of MoNE to maintain its services and transmit these services to all educational stakeholders. Within the scope of distance education, MoNE has decided to perform the courses via its online platform-EBA (Educational Informatics Network) and national television channel-TRT (Turkish Radio and Television Corporation). With the collaboration of MoNE and TRT, learning materials for distance education via national channels are prepared in a quite short time.

MoNE selected EBA as the main platform for distance education. EBA is a digital educational portal which is developed by MoNE and it is in service since 2011-2012 academic year. In this portal, various learning materials -including curriculum-based videos, documents, e-books, tests, activities- are provided to stakeholders of education from preschool to high school level. Students, teachers, and parents can access more than 5.000 books, hundred thousands of documentaries, cartoons and documentary in EBA portal. EBA is also a dynamic portal and gives diverse opportunities to students and teachers. Teachers can assign assessment tasks to students via EBA portal. In addition, the portal provides a tool to analyze the academic needs of students using data based on their responses to tasks. In this way, students can reach the materials based on their personal academic needs. Students can also select the topics which they want to focus on, and they can find the related online courses and assessments. Video recordings of courses can also be prepared and uploaded in EBA.

In EBA portal, distance courses are structured based on school levels. In primary and middle schools, all courses are presented to students between 09.00 and 14.00, and replays of courses are demonstrated between 14.30 and 19.30 with same order. For the students in secondary schools, distance courses are presented between 09.00 and 16.00, and replays of courses are demonstrated between 16.30 and 23.30 with same order.

An example schedule of distance education program from EBA TV is given at Table 1. As seen in Table 1, courses are presented to students in both primary schools, middle and secondary schools daily. At the end of distance education program, a specific program called as "parents' hour" is also presented. Consequently, EBA become an important educational source for all stakeholders in the times of COVID-19.

Tablo 1. An example of distance education program in EBA TV (April 13, 2020)

\begin{tabular}{|c|c|c|c|c|}
\hline Time & & $\begin{array}{c}\text { Primary School } \\
\text { (Grade } 1 \text { - Grade 4) }\end{array}$ & $\begin{array}{c}\text { Middle School } \\
\text { (Grade } 5 \text { - Grade 8) }\end{array}$ & $\begin{array}{c}\text { Secondary School } \\
\text { (Grade } 9 \text { - Grade 12) }\end{array}$ \\
\hline 09:00 & & Life Science - 1 & Turkish Language - 5 & Turkish Philology - 9 \\
\hline 09:30 & & Mathematics - 1 & Mathematics - 5 & Mathematics - 9 \\
\hline 10:00 & & Life Science - 2 & Turkish Language - 6 & Culture of Religion and Knowledge of Ethics - 9 \\
\hline $10: 30$ & & Mathematics - 2 & Mathematics - 6 & Turkish Philology - 10 \\
\hline $11: 00$ & & Life Science - 3 & Turkish Language - 7 & Mathematics - 10 \\
\hline $11: 30$ & & Science - 3 & Mathematics - 7 & Turkish Philology - 11 \\
\hline $12: 00$ & & Social Sciences - 4 & Turkish Language - 8 & Mathematics - 11 \\
\hline $12: 30$ & & Science - 4 & Mathematics - 8 & Turkish Philology - 12 \\
\hline 13:00 & $*$ & IYEP - Mathematics & * Arabic Language - 5 & Mathematics - 12 \\
\hline $13: 30$ & $*$ & Turkish Language for Adaptation & * Turkish Language for Adaptation & Exercise Hour \\
\hline $14: 00$ & $*$ & Info for Families & * Life Sciences & * Kuran-ı Kerim \\
\hline $14: 30$ & $\mathrm{R}$ & Life Science - 1 & R Turkish - 5 & * Arabic Language - 9 \\
\hline $15: 00$ & $\mathrm{R}$ & Mathematics - 1 & R Mathematics - 5 & * Basic Knowledge of Religion - 9 \\
\hline $15: 30$ & $\mathrm{R}$ & Life Science - 2 & R Turkish - 6 & * Metal Technology - 10 \\
\hline $16: 00$ & $\mathrm{R}$ & Mathematics - 2 & R Mathematics - 6 & * Information Technologies - 11 \\
\hline
\end{tabular}

*Selective Course/Course of Academic Support Program/Adaptation Course/Course in Program Type

R: Replay

Concurrently, all videos are presented to students from television via TRT. Students who do not have internet connection at home can participate the distance education opportunities via television. TV programs are transmitted via three different channels for primary, early secondary and secondary school students.

In pandemic days, it is critical to have a sustainable digital education portal such as EBA and qualified educators who can use the portal. Based on 2018 PISA data, Moreno and Gortazar (2020) show that most school principals think that an effective online 
learning portal is available in Turkey and teachers have necessary technical and pedagogical skills to integrate digital devices into the instruction.

\section{EBA Infrastructure is Strengthened}

MoNE made investments to strengthen the infrastructure of EBA in order to obtain a sustainable distance education portal. During this distance education period, access frequency of EBA has increased to great extent, and EBA has become one of the most frequently used websites around the world. Between the beginning of March and $12^{\text {th }}$ of April, EBA has been clicked more than 1 billion times, and the number of the access to EBA reached 900 million. EBA maintains the service with its strengthened infrastructure with high-volume of access.

\section{Free Internet Access to Students}

MoNE collaborated with the leading GSM operators in Turkey to support the students' access to the EBA online portal. Operators provided internet access to the students up to $8 \mathrm{~GB}$ free of charge. Students can use internet access to participate the online courses and other educational activities at the EBA portal.

\section{Live Courses for Students in $8^{\text {th }}$ Grade and $12^{\text {th }}$ Grade}

MoNE provided extra opportunities to support the students who has been preparing for the high-stake examinations in Turkey. For students who will take High School Entrance Examination (LGS) in $8^{\text {th }}$ grade, and those who will take University Entrance Examination (YKS) in $12^{\text {th }}$ grade, "live courses" via the EBA portal are available now. Accordingly, students can participate interactive courses and get feedback from their teachers. Moreover, MoNE has also started a new broadcasting channel via TRT to support students for these high-stake examinations during weekends.

\section{Revision of the High-School Entrance Examination Content and Automatic Registration of Students}

As mentioned above, High School Entrance Examination (LGS) is a high-stake test which is used to assess the academic performance of $8^{\text {th }}$ grade students and place them to high schools based on their choices and performance. In normal conditions, LGS is prepared based on the $8^{\text {th }}$ grade curriculum. Considering the possible inequalities in access to online and distance education, the content of LGS is now limited to only the first semester of $8^{\text {th }}$ grade curriculum. LGS is postponed from June to July. Accordingly, if there would not be any other delay, all $8^{\text {th }}$ grade students could take this multiple-choice test-which has a broad social legitimacy due to its objective assessment.

Due to the limitations as a result of social distancing, MoNE decided to register all students in $8^{\text {th }}$ grade to High School Entrance Examination (LGS) automatically. Therefore, students and parents do not need to go to school, register themselves or confirm the registration to take examination. Considering the number of students who take the exam, this regulation is quite important to keep social distance.

\section{Supporting the Professional Development of Teachers via Distance Education}

MoNE has prepared a professional development program for teachers in collaboration with UNESCO. To support the professional skills of teachers, 17 programs which focus on the diverse topics, were prepared and presented to teachers via distance education. Approximately, 125.000 teachers will participate the professional development programs during school closure period.

\section{Supporting the Psychological Resilience and Well-being of Students and Parents}

Social distancing and other limitations due to COVID-19 may cause negative psychological conditions such as anxiety and fear, and these may affect the well-being of students and parents. Along with the distance education, MoNE aims to support the psychological resilience of students and parents. To maintain the emotional health of students and parents, MoNE prepared psychosocial guides and shared them with the public. In these guides, students and parents are informed about the effects of COVID-19, and suggestions for parents to support their children's well-being are provided. Considering the differences in target groups, guides are presented in three versions: For families, adults, and youth.

Additionally, MoNE established a helpline for psychosocial support of students and parents. Psychological counselors from the General Directorate of Special Education and Guidance response the calls and help the students and parents to cope with undesirable effects of COVID-19. In all provinces of Turkey, 1,375 experts in Guidance and Research Centers (RAMs) are assigned for the supporting of psychological resilience of students and parents. This is the first comprehensive project by MoNE where students and parents can directly communicate with experts in all provinces of Turkey.

Students who need special education can be more vulnerable in times of crisis due to their special needs (ECW, 2020). For the students in special education, videos of specific courses and activities are prepared, and uploaded to the EBA portal. Educational materials with sign language support for students in special education are also added to the EBA portal. For the special education students and students with lower level of autism, more than 400 educational activities are prepared in diverse disciplines.

In cooperation with non-governmental institutions and foundations for disabled people, MoNE also prepared videos which focus on the self-care and fundamental skills of students. Additionally, for the students with diverse levels of autism, 19 
educational programs have been updated. Lastly, a mobile application (I am Special, I am at Home) has been developed and it is now available for special education students.

\section{Increasing the Production Capacity of Vocational Education and Training}

VET has been on the hot debated agenda of education systems for years (Ozer and Perc, 2020). Especially, after widespread use of automations in the production and service sectors supported by artificial intelligence technologies, this debate has been dramatically increased in terms of the new skill demands in labor market (Perc et al., 2019). MoNE has conducted multidimensional projects to improve VET in Turkey after declaring the Education Vision 2023 (Ozer, 2018). These projects increased the both quality of VET and production capacity of vocational and technical Anatolian schools (VTAHs). Many chronic problems have been eased since then (Ozer, 2018; Ozer, 2019a; Ozer, 2019b; Ozer and Suna, 2019; Ozer and Suna, 2020). With the increasing educationproduction capacity in VET, VET has become one of the main source of production for the needs of society during the initial shocks of COVID-19 crisis (Ozer, 2020). VET has an important potential to adapt its power in production towards the urgent needs, and its adaptation ability makes VET an important source in times of crisis.

MoNE made necessary investment on the pilot VTAHs for the production and positive outputs are obtained in a short while (Ozer, 2020). In this context, up to now, VTAHs reached at production capacities of 10 million of medical masks per month, cleaning material needs of all schools of about 54 thousand and the cleaning material needs of public institutions, one million face protection shields per month and one million disposable gowns and overalls per month.

MoNE has also spent a great effort on research\&development (R\&D) studies to increase the production capacity and in VET. MoNE constructed R\&D centers within VTAHs to produce different biomedical instruments such as mask machine and respiratory equipment. After one month efforts, both "3-Layer Wire Ultrasonic Surgical Mask Machine" and respiratory equipment have been produced.

\section{DISCUSSION AND CONCLUSION}

COVID-19 is a major problem all around the world, and the scale of the issue forces the governmental authorities to take strict precautions. As a result of these precautions, students and educators are highly affected by the COVID-19 pandemic. Due to social distancing measures, schools are closed instantly in many countries and countries strive for sustaining the educational services in these extreme conditions.

Due to high spreading of COVID-19 in Turkey, MoNE has decided to close the schools starting from March 17, 2020 until the end of April 2020 with the coordination of the Ministry of Health and its Science Council. With the prioritization of health and welfare of society, it is decided that all education will continue via distance education. Distance education is provided via the EBA portal as well as national TV channels. For TV broadcasting, MoNE collaborated with TRT and now broadcast educational materials through the three national television channels. Therefore, in COVID-19 pandemic period, students can participate the distance education via both online portal and television.

MoNE taken important steps to support the students in academic and social way in pandemic period. First, the infrastructure of EBA portal is strengthened to sustain distance education. As expected, EBA has become one of the digital education portals with highest members around the world. In order to increase the accessibility, MoNE collaborated with the main GSM operators in Turkey. Within the scope of protocols, students can access to internet up to 8GB free of charge. EBA has also been used for the professional development of teachers in pandemic period. In-service development program of teachers is also adapted to distance education.

To support the students who will take the High School Entrance Examination (LGS) in $8^{\text {th }}$ grade, and University Entrance Examination (YKS) in $12^{\text {th }}$ grade, MoNE established "live courses" practice in EBA portal.

MoNE has given much importance to improve the VET in Turkey since the announcement of Education Vision 2023. After implementing multidimensional projects to improve the quality of VET, it become an important actor for getting out of initial shock of COVID-19 by producing urgent materials in Turkey. In the initial phase of pandemic days, VET has contributed greatly to the production of the materials which are hard to find nowadays (Ozer, 2020). Cleaning material needs of the 54.000 schools around the Turkey has met by the productions of VTAHs. R\&D studies in VET accelerated, and machines for production of surgery masks and masks with N95 standard, and disposable materials are manufactured. Therefore, VTAHs have reached to capacity of 10 million masks and one million face protection shields monthly. Additionally, cleaning materials, masks, and face protection shields are shared with elderly people and those who need within a social service project in VET.

Due to the restrictions in social life and staying at home, people can feel anxious, scared or have negative emotions in pandemic periods. MoNE established a helpline to support the psychological resilience of students and parents. This is the first comprehensive project by MoNE which students and parents can directly integrate with counselors via telephone. Additionally, guides for families, adults and youth have been prepared to support people to cope with the effects of COVID-19.

For the participation of students in special education to the distance education, specific materials have been added to EBA portal. Number of the learning materials with sign language support have been increased, and new materials will also be added. New mobile applications are prepared to update students and parents about the developments in special education. 
In conclusion, MoNE uses all its potential to sustain education and to cope with the negative impacts of COVID-19 pandemic. As it is mentioned in this study, it is quite important to support all educational stakeholders in academic and social dimensions. The effects of COVID-19 created a challenge for all educational administrations across the world. Ensuring that all students have access to the distance education and other opportunities is crucial for educational authorities.

\section{REFERENCES}

Burgess, S., \& Sievertsen, H. H. (2020). Schools, skills, and learning: The impact of COVID-19 on education. CEPR Policy Portal. Retrieved from https://voxeu.org/article/impact-covid-19-education

Education Cannot Wait - ECW (2020). The fierce urgency of now!: Education in emergency response to COVID-19. ECW Policy Reports.

ETF (2020). Coping with COVID-19: Mapping education and training responses to the health crisis in ETF partner countries. Torino, Italy: ETF Publishing.

Hopegood, S. (2020). Coronavirus: Our principles, values, and shared humanity. Worlds of Education. Retrieved from https://www.worldsofeducation.org/en/woe_homepage/woe_detail/16719/\%C2\%AB-coronavirus-nos-principes-nos-valeurs-et-notrehumanit\%C3\%A9-commune-\%C2\%BB-par-susan-hopgood

Moreno, J. M., \& Gortazar, L. (2020). Schools' readiness for digital learning in the eyes of principals. An analysis from PISA 2018 and its implications for the COVID19 (Coronavirus) crisis response. World Bank Blogs. Retrieved from https://blogs.worldbank.org/education/schoolsreadiness-digital-learning-eyes-principals-analysis-pisa-2018-and-its?CID=WBW_AL_BlogNotification_EN_EXT

OECD (2020). A framework to guide an education response to the COVID-19 Pandemic of 2020. Paris: OECD Publishing.

Ozer, M. (2018). The 2023 Education Vision and new goals in vocational and technical education. Journal of Higher Education and Science, 8(3), 425-435.

Ozer, M. (2019a). Reconsidering the fundamental problems of vocational education and training in Turkey and proposed solutions for restructuring. İstanbul Üniversitesi Sosyoloji Dergisi, 39(2), 1-19.

Ozer, M. (2019b). Background of problems in vocational education and training and its road map to solution in Turkey's Education Vision 2023. Journal of Higher Education and Science, 9(1), 1-11.

Ozer, M., \& Suna, H. E. (2019). Future of vocational and technical education in Turkey: Solid steps taken after Education Vision 2023. Journal of Education and Humanities, 10(20), 165-192.

Ozer, M., \& Perc, M. (2020). Dreams and realities of school tracking and vocational education. Palgrave Communications, 6, 34.

Ozer, M., \& Suna, H. E. (2020). The linkage between vocational education and labor market in Turkey: Employability and skill mismatch. Kastamonu Education Journal, 28(2), 558-569.

Ozer, M. (2020). Vocational Education and Training as "A Friend in Need" During Coronavirus Pandemic in Turkey. Bartın University Journal of Faculty of Education, 9(2), 1-7.

Perc, M., Ozer, M., Hojnik, J. (2019). Social and juristic challenges of artificial intelligence. Palgrave Communication 5, 61.

Reimers, F. M. (2020). What the Covid-19 Pandemic will change in education depends on the thoughtfulness of education responses today. Worlds of Education. Retrieved from https://www.worldsofeducation.org/en/woe_homepage/woe_detail/16727/\%E2\%80\%9Cwhat-the-covid19-pandemic-will-change-in-education-depends-on-the-thoughtfulness-of-education-responses-today\%E2\%80\%9D-by-fernando-mreimers

Saavedra, J. (2020). Educational challenges and opportunities of the Coronavirus (COVID-19) pandemic. World Bank Blogs. Retrieved from https://blogs.worldbank.org/education/educational-challenges-and-opportunities-covid-19-pandemic

UNESCO (2020). How are countries addressing the Covid-19 challenges in education? A snapshot of policy measures. Global Education Monitoring Reports. France: United Nations Educational, Scientific and Cultural Organization.

UNESCO (2020, March 27). Teacher Task Force calls to support 63 million teachers touched by the COVID-19 crisis. UNESCO. Retrieved from https://en.unesco.org/news/teacher-task-force-calls-support-63-million-teachers-touched-covid-19-crisis 